ties of these objects. They ignore completely the fact that physical science has transformed the reality of the common-sense world beyond recognition. They make the naive assumption that the common-sense view of reality is a necessary requirement of physical science. So here, when we ask what is the existence which is distinct from the essence given in sense-perception, space and time and stuff are offered us as the unquestionable framework, ground, and criterion of existence. In this Prof. Strong has, of course, the new realists in mind. But why do the new realists persist in ignoring the evolution of mathematical and physical theory, the principle of relativity, the new concepts of space, time, and velocity, the new scientific world-view of a universe consisting of events and history, in their touching anxiety to save at all costs the common-sense reality of the plain man's world?

This is not intended as depreciation, but as an indication of the real difficulty I feel in regard to Prof. Strong's theory, with which I am in general agreement.

I would advise anyone whom this review may induce to read Prof. Strong's book to begin at the second chapter, entitled "Introduction," and defer the first chapter, entitled "Preliminary," until he has read to the end of the book. The "Preliminary" chapter, probably on account of its brevity and attempt to epitomise, is very obscure in comparison with the main argument.

H. WIILON CARR.

\section{BIOLOGY AND HUMAN IVELFARE.}

Civic Etiology: A Text-book of Problems, Local and National, that can be Solved only by Civic Co-operation. By Prof. Clifton F. Hodge and Dr. Jean Dawson. Pp. viii $+38 \mathrm{I}$. (Boston and London: Ginn and Co., r918.) Price 7 s. net.

r HIS timely book shows in a graphic way, thoroughly well documented, how much man might improve his place in Nature and his immediate environment if the available knowledge could be utilised in concerted civic action. The coloured frontispiece contrasts an earthly Paradise in Oregon with man-made desert conditions at Shingkung, China, and the idea of the book is : "Which?" "Discovery is pushing forward in every direction as never before in the history of the world, and still it would seem that enough is already known to make living well-nigh ideal and the world almost a paradise, if only enough people knew." Yet "probably not less than five hundred thousand valuable lives are sacrificed annually to the currents of preventable disease, along with the several billions of dollars' worth of foods and other property swept away by rats, insects, weeds, and fungi.", Unco-ordinated individual effort can do little; co-operative scientific control backed by goodwill offers our only hope of success. "Our education needs to be so organised that every citizen shall know enough to stop a breach the instant he sees it.',
The course of instruction mapped out in this book is thoroughly practical and on sound educational lines, as one would expect, of course, for Prof. Hodge is the author of perhaps the wisest of all books on "Nature-study." Rats cost the States some five hundred millions of dollars every year, besides losses inestimable in money, and injurious insects are three times as costly as the rats. This sort of fact occupies a prominent place in the book, and the practicable measures of control are made so clear that he who runs may read. Thus to make the most and the best of the bird life is an obvious communal duty. (We notice, by the way, that the authors refer to the survival of an old passenger pigeon in the Cincinnati Zoological Garden. The death of this bird was reported in England some considerable time ago, but this may have been an exaggeration.)

The inquiry broadens out to include discussion of the following and much more: the careless felling of trees and the disasters of forest-fires; the control of weeds (which do annual damage to the tune of five hundred millions of dollars); making a back door beautiful; the improvement of cultivated plants and domesticated animals; the campaign against flies, mosquitoes, and other serious pests; the control of fungoid and bacterial diseases of plants, animals, and man; the life-histories of parasitic worms; the cultivation of clams and Crustaceans; the improvement of fisheries; and the utilisation of genctics as a basis for eugenics. It is a wide ambit, but the authors are to be congratulated on the skill with which they have used common things to illustrate general principles, and have thrown the light of general principles on common things. So while the course is frankly utilitarian, it is at the same time a discipline in the methods of science.

The book ends with a lively chapter on "Knowing How to Know How," and another on the progress of scientific discovery. The authors are quite sound on the practical value of theory, but they naturally lay emphasis on even the simplest endeavours to face the facts (of any order of magnitude and intricacy) without blinking. They are at one with Goethe when he said: "The most pernicious thing in the world is active ignorance", (or words to that effect), and with Emerson when he wrote: "I am impressed with the fact that the greatest thing a human soul ever does in this world is to see something and tell what it saw in a plain way. . . To see clearly is poetry, philosophy, and religion all in one." We are heartily at one with the authors in their exposition of what biology may do for human welfare; our only doubt is whether they have put in savingclauses enough. For there are some readers of easy ambitions who may be tempted to think that all will be right with the world if we get rid of rats and hook-worms, if we control weeds and flies, if we take Pasteur and Mendel into our everyday confidence. Hopes so sanguine will meet, we fear, with bitter disappointment.

J. A. T.

NO. $257 \mathrm{I}$, VOL. IO2] 